\title{
Facebook hiring in achievement knowledge and skills In the basics of information systems to the students of the Division of Computer Science
}

\section{Dr. Reham M. Issa}

The Higher Institute of Computer Science

(Management and Technology \& Information)

Kafr El Sek University

\section{Introduction}

The world has witnessed great changes in the form of life and held the knowledge and learning in the current era of heart place as a source of wealth and a measure of power among nations, and has become the use of digital technology Digital Technology Represented in the Internet a necessity for the success of any education system is to provide knowledge and learning, Learning-mail today a reality undeniable and does not need anyone who proves its importance after he proved his presence and effectiveness and thus contributed to change the features of the educational system.

The Networks Communication Social networks Across Inter net From Latest Detachments Revolution Informatics And most popularity Although that this Sites Established communicate Social between Individuals Except that Used sprea d To include all Grove Political And social And cultural ) and networks Communication Social as such Mentioned) Saadani And Hussein , 2012 M:261) She phrase About Communities Available Across Internet Composed From People Share In Concerns And activities as such Availability this Networks Ways several And variety Users Interaction; From During Conversation or Correspo ndence or About Road Mail-Mail

(Jewels Girl apparent Mohammed Anzi 0.2013)

It is no longer the role of social networks limited to communicate with friends and exchange of social and political debates, but that role much beyond that as many companies in the exploitation of these sites to promote their products and to 
connect with the target audience begun, as governments used them as well as for the dissemination of data and information and to receive views and comments by Community members.

On the academic level has started a lot of faculty in international and Arab universities members using these networks to communicate with the students in order to create a transparent and interactive learning environment where the student is an actor involved in the responsibility, not just a recipient of negative information being taught her teacher in a Hall school.

The first goal of the Web had to be a tool for scientists manage through which to share information and discuss the results of the pilot experiences, and this means that they were the nucleus of social software since early use them, and today is increasing sophistication in Web technologies and flowing into the return to the first use (Conference, 2005) : It's the network that is created by people and the first goal is the same people and not the content, so it can be called as the link network, which continue to grow in two directions in order to facilitate found on $\mathrm{Z}$ of people and content people Asnao $\mathrm{n}$ their own needs on the Web.

And there are three points of view translate the second generation of Web properties (Bram, 2007) :

1. Asiologih point of view: see Beners-Lee, 2 005) ) 2 that the Web is more like a dual channel applied through reading and writing activities read-write web Two-way by users and this is what ensures its enrichment and continuity, and for this, the Web 2 is about people and relationships they create through the use of software. The description(Tim 0 'Reilly, 2005) Web 2 as: the structure of the Post: base to use, self-regulating, make up the cooperative network.

2. And technical point of view: the Web 2 is a mix of working environments and languages used in the previous generation of the Web, which proved to be 
effective in creating applications via the Web browsers, such as: JavaScript, the Document Object Model, CSS, XML .

3. And economic point of view: subject Web 2 to the desire of the consumer in terms of building content and adapt it according to the user's personal needs and desire.

Web and these characteristics into a collaborative Web Collaboration Web: It is a new tools that facilitate participation in the tasks on the net where users can easily edit documents and conduct live interviews and arrange data and information and cooperation with other parties within the Web community without having to leave their places, but all of this is done through the Web. However, the browser that we wise up to that figure in the evolution of user Web 2, where the user has become more able to build his own Web site: work activities, learning, and social relations and this became known to this generation: the digital generation "Digital natives", "ngen" ( downes, 2005 ) , ( Marc, 2001). (Girl Ghada Abdullah Alamoda- Jeddah).

In an age of information and free access to information, a category of associate emerged educational field demanding freedom from restrictions of e-learning management systems and seclusion, and replace them with more open systems keep pace with the rapid changes in Web technologies, it was stated ( Hotrum, 2005 ) And( Dalsgaard, 2006 ), Learning management systems do not necessarily support the social constructivist approach to learning ( social constructivist approach) Which emphasizes self-learning and regulates the activities of the students.

With the development of the Internet and increase the speed of the concept of e-learning and ways of introducing change and interact with it to include aspects of more interactive, leading to the emergence of the so-called second generation of elearning (E-Learning 2.0). This type is interested in employing social programs such as blogs (Blogs) And wiki (Wikis) And others in the educational process. (India girl Caliph Suleiman 
0.2010) Confirmed "Trentino" and "Hoffmann" and "Press" (Trentin, 1999;Preece, 2000; Hofman, 2003)

Learning via the Web is a modern educational methods to education in small groups, as defined by a "Bantz" Wiersma "( Panitz, 1996; wiersaia, 2000 ) That philosophy of education: where depends on the interaction of the educated personalities and way of life, and that when the learners are responsible for their learning, and their respect for their abilities and contributions to complete the work, and the infrastructure to him on the basis of cooperation by members of the group, as compared with their competitors in other groups, and this philosophy is suited to today's globalized world "and is based on a set of principles:

1. This work leads to a better product in the achievement and skills and improve social relations better than working individually.

2. Spoken and audio-visual interactions between learners contribute to greater understanding.

3. It helps to increase the awareness and understanding through their experiences, social relations, including Alentvaalh.

4. Participation in education over the Web is free and voluntary.

There are two main principles that the They are learning across the web :

1. No person knows all Something for nothing

2. Each of us has something to give him And what the .

Moreover, studies Modern educational proved That there are seven practices If the educational process This used to be The process of sound The effectiveness and the impact of large, These practices are :

a. encourages interaction between The teacher and learners .

b. To encourage cooperation between Educated themselves .

c. provide feedback Links . 
d. encourage active learning And effective .

e. provide enough time To learn .

f. And sets high expectations The results of the operation And educational levels Learners (expect more Find more responsive).

g. is understood that And several types of intelligence Learners learn methods Different.

These practices are all Can be achieved and do Through participatory learning. (Slaves, Thuqan Suhaila Abu semolina, op. Cit.) .

And from the most important benefits provided by learning through Web 2.0 development of individual responsibility and collective responsibility, and the development of the spirit of cooperation and teamwork among the educated, Which helps them to exchange ideas and respect for the opinions of others and accepted. And train them to solve the problem or contribute to solve them, and then grow to have the ability to make decisions, and grow their self-confidence and the ability to express feelings and thoughts through the activities, field visits and dialogue with specialists and discussion among colleagues, and Breaking the of their teamwork difficulties .. Also give them and connect and communicate with others driving skills, because they keep them from receiving information routine, and through which to get to know the surrounding reality and touching and interacting with him, but to do the activity in the form of groups play a significant role in the consolidation of relations between the learners on the one hand and between them and the school on the other hand, and then the exchange of experiences and information through discussion constructive dialogue, have proved they are more useful and fun than individual learning, because it sums up the time and effort and is educated about selfishness, and strengthens their ties of friendship and develop personal relationships, and helps link the slow learners members of the groups and develop their integration (Encyclopedia of education and training 0.2009 ) 


\section{Of Facebook}

It came the idea of creating Facebook through the dream of a Harvard University student Mark Zuckerberg pedophiles computer named Mark Zuckerberg When sat a $\mathrm{m}$ a $\mathrm{m}$ personal computer screen in his room dwellings students at Harvard America, and began designing a new website on the Internet, it has a clear goal, a website design combines his colleagues at the university and enable them to exchange news and photos and opinions. And think Zuckerberg, simply Create a website to facilitate communication between university students on the basis that if such communication was successful, the SICO his popularity sweeping process. Hence came the idea of a $\mathrm{T}$. Facebook site

Wei has enabled the definition of Facebook as a p MOQ Web works on making friends and helping them to exchange information and personal photos and videos and comment on the possibility of easy form relationships in a short period. (Ibrahim mouse, 2012: 201)

The role of social networks in university studies.

Spin a lot of questions about the importance of social networking in college, and on top of these networks - Facebook- MySpace, And these are some points that deserve to stand out:

1. All of these networks are fixed, regardless of the type or the computer system used to run, or even your browser.

2. It's great to use unfamiliar with a large section of externa Lab and thus will obey my students to complete their discussion outside scientific grade of what will enrich the scientific article tools.

But at the same time:

1. Students have annoyed you are in for their page, and find in this infringement on personal freedom.

2. Some students may not have an account in these networks, but they can always establish a provisional account. 
3. Some students can not distinguish between what is academic and what is a personal interview.

4. May encounter problems as a professor in the privacy of the information published, or maintain its property rights, which could be avoided by using the multi-privacy systems provided by these networks.

\section{Facebook in Education:}

Use social networking Web 2.0 technologies to reach all individuals together effectively in a meaningful way and thereby creating an active and educated this can be summarized in the utilization of social networking (Facebook) in Education in :

1. Create the teacher or the student group or page of a substance or the subject of an educational and invite students to participate in it and the exchange of information, dissemination and exchange-page article on the subject or links.

2. publication of photos and video clips of appropriate educational material and exchange between students and those interested in, and comment on them and discuss them.

3. make friends and relationships with those interested in substance or a particular educational theme from all over the world and the exchange of information and experiences among them.

4. use it as a means of continuing the relationship between the graduates to continue learning and self-development in the same specialty.

5. used as a means to invite students and other various educational events.

6. used as a means for the exchange and dissemination of information and access to new information in the different disciplines. 


\section{Facebook Applications:}

Many applications have emerged with Facebook (Facebook app) It can be used in the field of education which is the electro Ne agencies to:

1. All movements recorded on the desktop through the can Webinaria Screencast Recorder Add your voice and operation of the full Alobb at the same time to work a lesson or illustrate or record a show with voice annotation and then Add in the Advanced Page and share all manner of practical and easy .

2. If you own the account of Slade Sher - a site that combines the many offers and allows upload and download to share with others - can be included presentations of slide Shi R. (Slide Share) For Facebook easily by this application and synchronize .

3. To add lessons, activities and courses by uncle Courses, Manage, and share, the opening chapter of the discussions and upload and share files .

4. To do your own application quick test . by Quiz Creator

5. Action to vote and taking the views $\mathrm{p} \mathrm{Li} \mathrm{different} \mathrm{topics}$ you create through Poll

\section{system schoology :}

Of these modern systems site ( schoology. com), Which offers a free service for creating and managing learning systems, and interface blends social networking with learning management tools, so that teachers and students (and parents and administrators) and all the people of communication and cooperation in educational matters. The site provides traditional educational functions in the months learning systems such as Albulakpord Blackboard And Model Model, So when we use schoology We can in the end that we find it possible to be used with Facebook properties Facebook Learning management system in order to be a stronger and more effective. 


\section{Facebook features:}

The first is characterized by Facebook site collects a lot of applications (Web 2.0) containing a number of sites which, although sometimes less quality and features, Facebook site on the camp includes the following:

1. M small notation: You may substitute for Moaf microblogging Katawaitr Twitter And similar sites.

2. Add your participation and the possibility of learning j s pictures obviating Flicker Obviates the sites involved pictures and comment on them Calflker Flicker And other similar sites.

3. Add your participation and the possibility to comment on clips You Tube Audio or video have sung for Mraca participate and comment on them, such as YouTube You TubeAnd other similar sites.

4. Post links to friends obviating sites del.icio.us And other sites.

5. Mail and chat may obviate EBAY And other similar programs.

6. Add feedback has sung about blogging Blogs And forums Forums .

7. Add a public or private events and the possibility of inviting Google Friends by what Aanyan sites Calendar C a l e rnd ar Of Google and other similar programs.

8. Add or accession to the pages or groups in areas such as dialogue wiki Wiki

Secondly: It is the most famous social networks and Web sites (0.2) and most generally used the neighborhood is the fourth most visited websites in the world according to the classification Liska - The number of participants has exceeded 500 Million users.

Third: The interface is in Arabic and English-language interface discretion of the student or the person who deals with the site. 
Fourth: Free with no versus's.

Fifth: ease of AST his servants so that it can be used Hamia pupils, students and general education from first grade to the third secondary grade, but the site is currently not allowed to register the age of 13 years, any primary school students and first-graders about middle school. (Ibrahim mouse, 2012: 207)

There are many Research that indicated the effectiveness of Facebook in teaching and learning processes, including:

Study (Jewels girl Mohammed Zahir Enzi 0.2013) and is entitled: the effectiveness of the use of social networks in the collection of science and the trend towards a knowledge society with Average third-grade students in Medina , The current study aimed to investigate the effectiveness of the use of social networks in the collection of science and the trend towards community Knowledge of the average third-grade students in the city of Medina and detect the presence of correlation, or lack thereof between the collection Science and the trend towards a knowledge society, and applied study on a random sample, strength of 63 students of whom 32 student represent experimental Aljmuah 0.31 student representing Aljmuah control, and the results were the presence of statistically significant differences between the average scores of students in achievement posttest for the experimental Aljmuah, and therefore the study recommended the employment of network communication asocial Facebook in Most of the teaching curriculum, as well as the parameters included preparation skills programs dealing with social networks.

Study (Dilshad Mohammad Sharif at 0.2012), titled «the effectiveness of a training program for the development of social communication skills among a sample of autistic children». The study aimed to verify the effectiveness of the training program for the development of social communication skills among a sample of autistic children, and included a sample study on 12 children and a child was diagnosed with autism classic based on the autism criteria in the Diagnostic Mental Disorders Guide, and 
the results of the effectiveness of the training program in the development of social networking with all the skills dimensions.

study (Pew Research Center 2012) And titled "Civic Engagement in the Digital Age", it decided $43 \%$ of social networking users to expand their knowledge about a political or social issues after he briefed them for the first time across social media sites, and $18 \%$ have taken decisions on a political matters based on materials have read through these sites. Included in the study of American adults in 2253, in the age of eighteen and above. The targeted measure of political interaction online and off with the role of social networks care during the year, and conducted in the period between between July 16 and August 7, 2012, and addressed to study the factors affecting the political participation; While commonly engage in political activities online and traditional channels between people with the highest income and education, income level does not affect the same degree when looking at social networks, and it remains the impact of educational level - such as university study - Clear; Both tertiary educated people more inclined to participate in political activity across social media, compared with graduates from high school.

Study (Maher Arafat 2011), titled «social impact of the educational use of social networks, with Facebook the Faculty of Information Technology students at An-Najah National University». The study aimed to determine the effect of communicating via the Facebook social relations and the process of study in order to stand on the negative aspects and positive aspects on the management information systems students in information technology - Najah National University, and included a sample study on information technology students at An-Najah National University of males and females by $50 \%$ to $50 \%$ different from the four academic years from first to fourth, and the results were that there are important points to be carried out to enable the community to achieve the greatest benefit from Facebook so that it is compatible and harmonious with the fact that society and its goals and ambitions, namely: 
1. Deepen and disseminate the idea of Facebook and parents informed him into entering the socialization process in order to achieve the objectives of the community.

2. Educate its users the best way to deal with it in order to be communicate reduces moral losses.

Mordant study Faris Al-Otaibi (2011), which dealt with Facebook and used by college students, lies the importance of the study To reflect the reality of being a And patterns of use of Facebook and study aimed to show the most prominent motives That pay students To use it, as well as Alachaabaat earned him and the resulting effects To be Benefit from the positive uses and try to overcome the disadvantages and activating use In the educational process. The study sample of students in the preparatory year from three universities Saudi universities Namely: King Saud University, King Faisal University - University of King Abdul Aziz was the results of the study illustrate the widespread use of Facebook among students Saudi universities by $77 \%$.

study (Bialik, 2010) And that The results of an Australian study conducted by Carl Bialik, I ran on a sample of (2000) of Facebook users volunteer their ability to solve problems more than non-users and that they are more productive. These results have confirmed a survey conducted by Ohio State University in 2009, which added that the cumulative average GPA For these students ranged from (3.0) and (3.5) and is excellent at what researchers think.

study Tiffany et al. Tiffany et al., (2009) The study aimed to provide descriptive information regarding the use of social networking sites by college students, formed the research sample of 92 students from undergraduate students at a private university in the United States, and in order to achieve the purposes of the study, the researchers apply a measure such as Notepad on the research sample, It contains seven questions to measure using a specific time each day for a week, where students score much time that has been spent in the use 
Facebook daily, and the activities they have done every day. After the completion of the application Notepad scale was given the students 24 hours to complete the survey by scale contains 54 divided the question into two parts, the first part the students answered 31 questions about their activity on Facebook in the week was the Notepad scale data collection, and in the Part II answered the students on the 23 question of open-ended questions that revolve around why students of social networks, especially Facebook sites is used, and how they interact with each other on that site, and the results showed that students spend an average 30 minutes a day on Facebook as part of their daily routines and that 85 percent of college students use Facebook for social interaction with friends who have a relationship with them before, and that about only $9 \%$ used Facebook to make new friends, and students who participated in the study pointed out, that the social networking Facebook network already caused to change their lifestyles.

Devitt study Dan (2008 Dan,) Where The researcher studied in order to identify how Facebook contacts in the world the truth, and found that Vespo as a significant impact on people's lives, where the majority call several times a day for listening and viewing. The negative effects resulting from excessive Alastkhadda $\mathrm{m}$ and talk for long periods.

\section{2. sense of the problem:}

I noticed a researcher from the reality of teaching and having difficulty in absorbing students with the decision of computer networks in the basics of communication systems data and as the networks of decisions which are difficult to learn by Demonstration for the content of the skills is difficult for students to understand the statement pragmatic without a network configuration, so there was a need desperate for work Page (group) On the interactive Facebook contributed in the acquisition of communication skills, and the researcher doing a poll for the students to find out the extent of the difficulties they face in the study of the practical part of the network which is as follows: 
- An internal network for the lab's work is connected between devices to exchange data .

1. simplified model system for contact (Simple Communication System) :

1. The first model - Telephone call.

2. The second model - Use the computer to connect to the Internet.

2. transmission patterns (Transmission Modes) :

1. Send in one direction, "simplex" (Simplex)

2. Send in two directions at the same time "Full Duplex" (Full Duplex) .

3. Send in two directions, but not at the same time, "half duplex" (Half Duplex) .

3. transmission constraints (Transmission Impairments) :

1. decay distortion (Attenuation Distortion) :

2. delay distortion (Delay Distortion) :

3. LNB (Noise)

4. Edit Bookmark (Signal Modulation) :

1. amendment typical signals (Analogue Signal Modulation) .

2. modified digital signal (Digital signal Modulation) .

It turns out a poll the number of students who have difficulty in absorbing the pragmatic decision networks, $91 \%$ of the total number of students.

\section{Find a problem}

Having difficulty in absorbing students decision Alha Sep automation networks in the basics of communications systems.

\section{Research Sample:}

Was split Division of Science students of Computer Higher Institute of Management and Information Technology in Kafr ElSheikh, totaling 60 students into two groups at random experimental one of them and the other officer by (30) each A, it has been confirmed researcher of equality of the two groups in each of the test grades and card observation. 


\section{Borders Search}

Find the current is determined by the following limits:

1. random sample of students of Computer Science Division of the Higher Institute of Management and Information Technology in Kafr el-Sheikh.

2. collection of knowledge in the basics of data communication systems.

3. performance skills in the basics of communications systems.

\section{Research Objectives}

The current research aims to:

1. Verification of employment with Facebook in the basics of communications systems cognitive achievement level of the students.

2. The development of performance skills in the basics of communications systems to the students of Computer Science Division of the Higher Institute of Management and Information Technology, Kafr El-Sheikh.

\section{The importance of research}

The importance of this research:

1. attempt to produce group The interactive tutorial contributed to the increase cognitive achievement with the decision of computer networks.

2. attempt to develop performance skills in the basics of communications systems among students.

3. an attempt to shed light on the importance of dealing with the students give the network using one of the second generation of the Web, "Facebook" technology skills.

4. represents a substantive response to what is spoken of educators narrators of the need to benefit from the advantages and potential of new technologies in the educational process, and what they can contribute in overcoming some of the problems of education of increasing demand for education, and increase the 
number of students, and the possibility of overcoming this type of education within space and time.

5. scarcity of Arabic studies on Facebook _vi Albagesh_ aware of the limits which may confer on this research along with leadership and initiative.

\section{Research Methodology}

This research of the experimental approach is used, which aims to examine the impact of independent variables on the dependent variables.) Tribal - after me ( $x$ ) DEMO - officer (

\section{Find variables}

1. independent variable: Teaching networks by decision group T. Oluyemi TVA p Lee on Facebook

2. The dependent variables: - cognitive side in the basics of communications systems .

3. Performance skills in the basics of communications systems .

\section{9. materials and research tools}

1. Learning strategybased on the Facebook basics of communications systems, the decision of computer networks.

2. G roup Interactive educational basics Communication Systems decision of computer networks.

3. Test the basics of cognitive achievement Communication Systems .

The test was the achievement of the cognitive content with the decision and presented to the arbitrators to conduct the proposed amendments by the preparation, where they are in the finalization of a number (46) and Tveselhm question as follows:

\begin{tabular}{|c|c|c|c|}
\hline $\begin{array}{c}\text { The number of } \\
\text { questions } \\
\text { Type }\end{array}$ & $\begin{array}{c}\text { The number of } \\
\text { questions } \\
\text { True or false }\end{array}$ & $\begin{array}{c}\text { The number of } \\
\text { questions } \\
\text { multiple choice }\end{array}$ & Total \\
\hline Tdkr & 9 & 5 & 14 \\
\hline understanding & 6 & 8 & 14 \\
\hline Application & 13 & 5 & 18 \\
\hline Total & 28 & 18 & 46 \\
\hline
\end{tabular}


Account validity and reliability test of knowledge:

Honesty: the researcher - in addition to the sincerity of the arbitrators - calculates the sincerity of internal consistency as measured by with transactions Alartb framework between each individual and the total for the test, which ranged between (0.436), (0.431), a function at the level of (0.01) was also correlation coefficients between the three dimensions and the total account were: For after remembering $0.865=$, and after understanding $0.755=$, and after the application $=0.831 \mathrm{a}$ function at the level of (0.01).

Persistence: s blamed researcher Bjdzisab test the stability of Boutriqi T. yen as follows:

1. Fly me Ge Cronbach's alpha = was 0.866 a reasonable

2. Split the way of the busts of Jtman it was $=0.544 \mathrm{a}$ reasonable too.

Note Card to measure the basics of communications systems Skills:

The card counter E. Note include the basics of communications systems and presented to the arbitrators to conduct the proposed amendments thereto skills and become finalized composed of a number (34) skill distributors eight key skills are as follows:

\begin{tabular}{|c|c|c|}
\hline $\mathbf{M}$ & Skill Home & $\begin{array}{c}\text { Number } \\
\text { of sub-skills }\end{array}$ \\
\hline 1. & Dealing with skills Oscilloscope & 5 \\
\hline 2. & Dealing with skills Signal generator & 5 \\
\hline 3. & $\begin{array}{l}\text { Amendment wave amplitude in the signal } \\
\text { stereotypes }\end{array}$ & 5 \\
\hline 4. & $\begin{array}{l}\text { Amendment wave frequency in the signal } \\
\text { stereotypes }\end{array}$ & 3 \\
\hline 5. & Amendment wave signal typical angle & 4 \\
\hline 6. & $\begin{array}{l}\text { Amendment wave amplitude in the digital } \\
\text { signal }\end{array}$ & 5 \\
\hline 7. & $\begin{array}{l}\text { Amendment wave frequency in the digital } \\
\text { signal }\end{array}$ & 3 \\
\hline 8. & Amendment wave digital signal angle & 4 \\
\hline \multicolumn{2}{|r|}{ Total } & 34 \\
\hline
\end{tabular}


Account validity and reliability of the note card:

Honesty: the researcher - in addition to the sincerity of the arbitrators - calculates the sincerity of internal consistency as measured by with transactions Alartb framework between each sub-skill and the total for ducks $s$ of which ranged between (0.756), (0.711), a function at the level of (0.01) was also correlation coefficients between pain Account A Rat eight major grand total were:

For the skill to deal with Oscilloscope $=0.699$

And skill to deal with Signal generator $=0.655$, And skill adjustment in the signal amplitude typical $=0.516$

And skill in modifying the frequency reference module $=0.611$

And skill wave angle adjustment in the signal stereotypes $=0.599$

And skill in modifying the amplitude digital signal $=0.584$

And skill in modifying the frequency digital signal $=0.546$

And skill in modifying the angle of wave digital signal $=0.532$

They function at the level of (0.01)

Stability: S blamed researcher Bjdzisab firming note card Boutraguet yen as follows:

1. Mushy of Cronbach's alpha $=$ was 0.766 a reasonable

2. Split the way of the busts of Jtman were $=0.566$ who is also reasonable.

\section{Search Terms}

\section{The second generation of e-learning}

Tim is known Orly ( O'Reilly, Tim.2008) Web 0.2 "Are selfservice and data management calculations carried out by the Internet user to gain access to the full contents of the Web." The Egyptian National Council for e-learning knew the second generation of e-learning as:

"It is interested in supporting the social aspect of the educational process compensation detachable spatial between the teacher and the learners through the use of social software (software that enhance the partnership and communication between learners) such as blogs, wikis and the formation of 
communities of learners and voice broadcasting and broadcast video and social networking. The exchange of links to the web through Marking the important links help the learner to know others with similar interest "programs (the Egyptian National Center for e-Learning, 2008).

\section{social networks :}

Interactive Networks is a software, allows people to interact on an idea or a theme or a particular goal, you can, for example, any school that has a special code arise, and allows students the ability to write their own affairs for the school or the school, or even about Greek literature! In another definition, we can say that social networking group of individuals, often called -osedka - linked together in a way Ma.tstkhaddm name social networking Web 2 technologies to reach these individuals together, effective in a meaningful way. The use of social networking technologies, built-in Web 2 technologies, creates an effective education, especially if they are used correctly and efficiently.

\section{Facebook: English : (Facebook)}

it is social network It can be accessed for free and run by the company "Facebook" limited liability As private property her. (For Mays Shalash 0.2013), and is the Facebook of social networks, which had been in great demand by People as it once you have registered and where you add your friends and acquaintances to your And then communicate with them through chat and post photos and the latest developments on In the beginnings of your wall appearance was the goal of its founder Mark Jokrberg - site design combines His colleagues at Harvard University and enable them to exchange news and photos and opinions. Since the Today's generation is known as the "generation Alvesbuque" You'll note that most of the University students They communicate through Facebook, this written comments and that image is attached and that creates Page Revolution . 
The defined (right Council, 2011) as a site like other sites for publication, easy to use in which the owners of all stripes and Almarb find different orientations rapier mainly it depends on the purpose for which the interference from him.

\section{Hypotheses:}

It enabled the formulation of a main hypothesis

\section{follows:}

There are statistically significant differences at the level $(\leq$ 0.05 ) between the mean scores of the two groups students (Altjeribh and control group) in the collection identifier $\mathrm{j}$ and skills unit and modes of communication among students of the Division of Computer Science at the Higher Institute of Management and Information Technology, Kafr El-Sheikh for the experimental group.

\section{Which fork to the following counts:}

a. There were statistically function teams at the level $(\leq$ 0.05) between the mean scores of the two groups students (experimentation me of and control) in the cognitive achievement of unity and communication media the decision of computer networks automated with the students of the Division of Computer Science at the Higher Institute of Management and Information Technology, Kafr El-Sheikh for the experimental group.

b. There were statistically function teams at the level ( $\leq$ 0.05) between the mean scores of the two groups students (Altjeribh and control group) in the performance skills unit and media decision of computer networks to the students of the Division of Computer Science Higher Management Institute, information technology, Kafr ElSheikh for the experimental group.

\section{2 - Search Procedures}

1. Review of the literature and previous studies relevant to Find 
2. Review of the views of specialists to determine the necessary basic skills communication media connected to the network were:

1. Skills Contact In the network

2. Skills Determination Structure the network

3. Skills design the network

4. Skills establishment of a wired network between two devices

5. Skills establishment of a wireless network

- Choose the tools and pieces and routers routers

- Delivery of parts and tools

- Adjust the settings of parts and tools

- Protection settings

- Connect his computer to the network

- Skills scan Crashes the network .

3. Determine the educational content with the decision elements and the preparation of the scientific content associated with them in the light of the overall objectives of the decision:

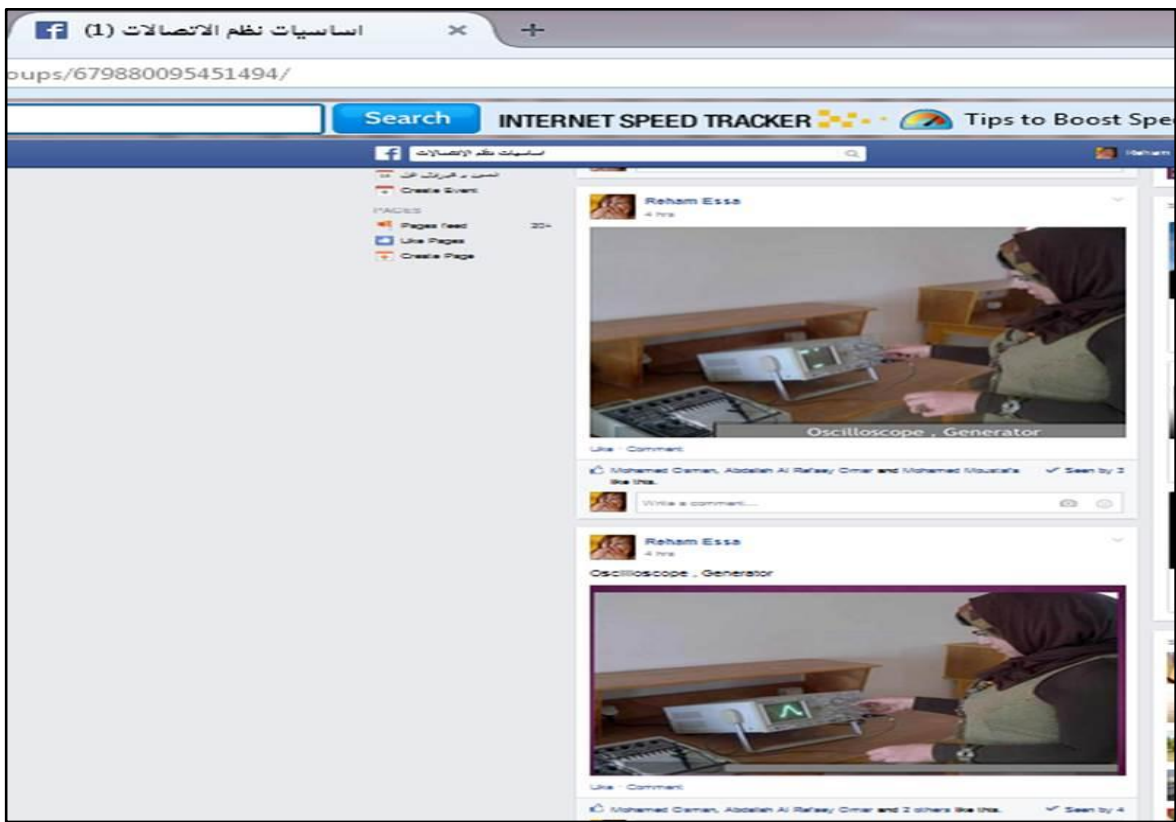



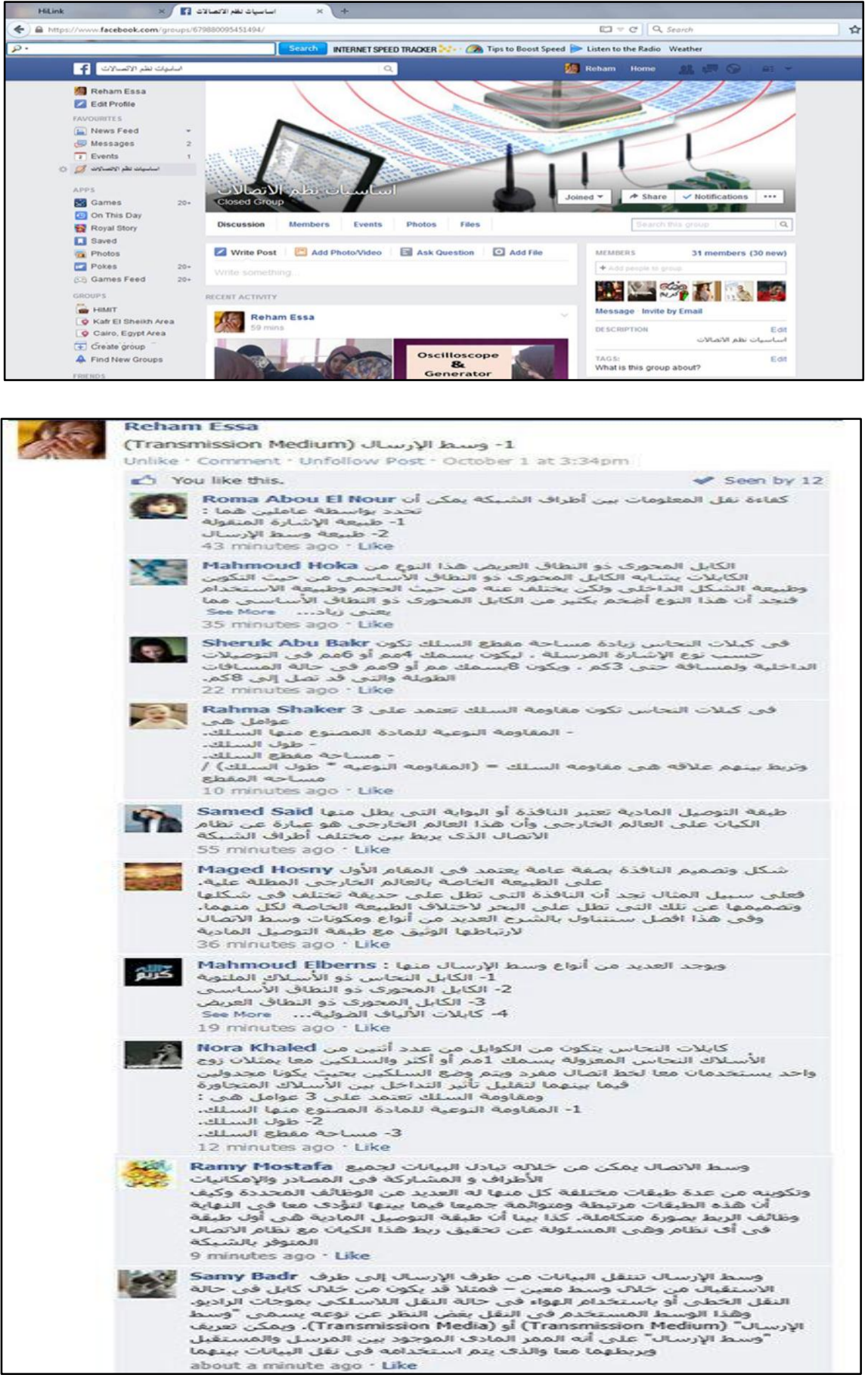

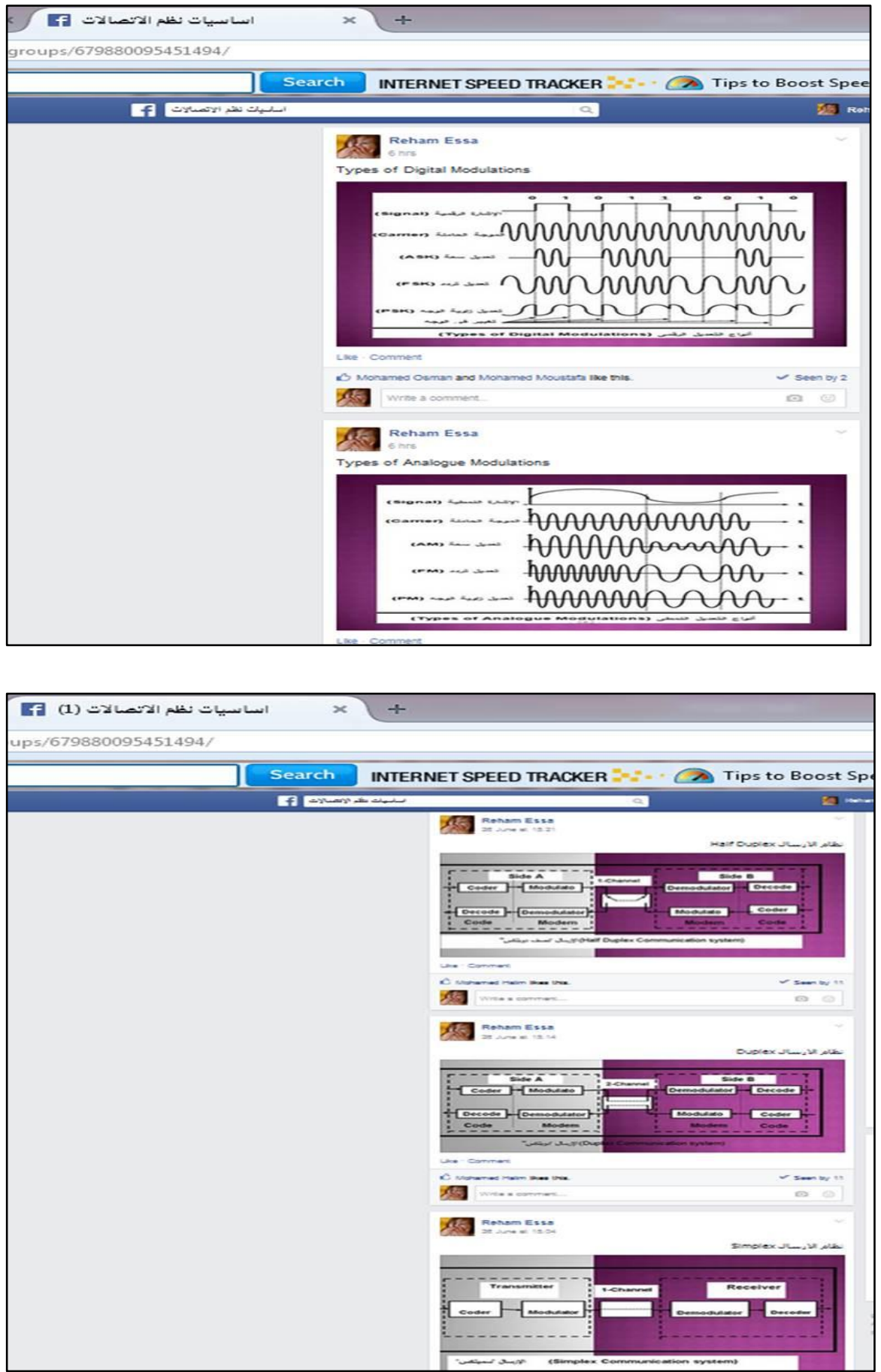


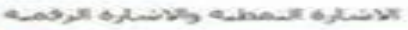

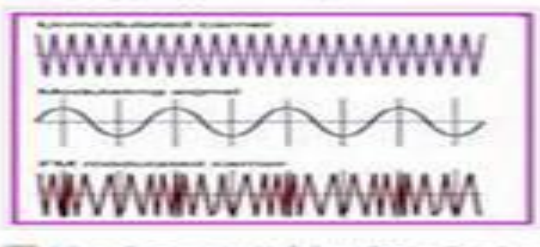

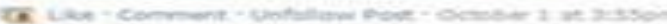

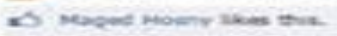

16 Nher 27 more commens

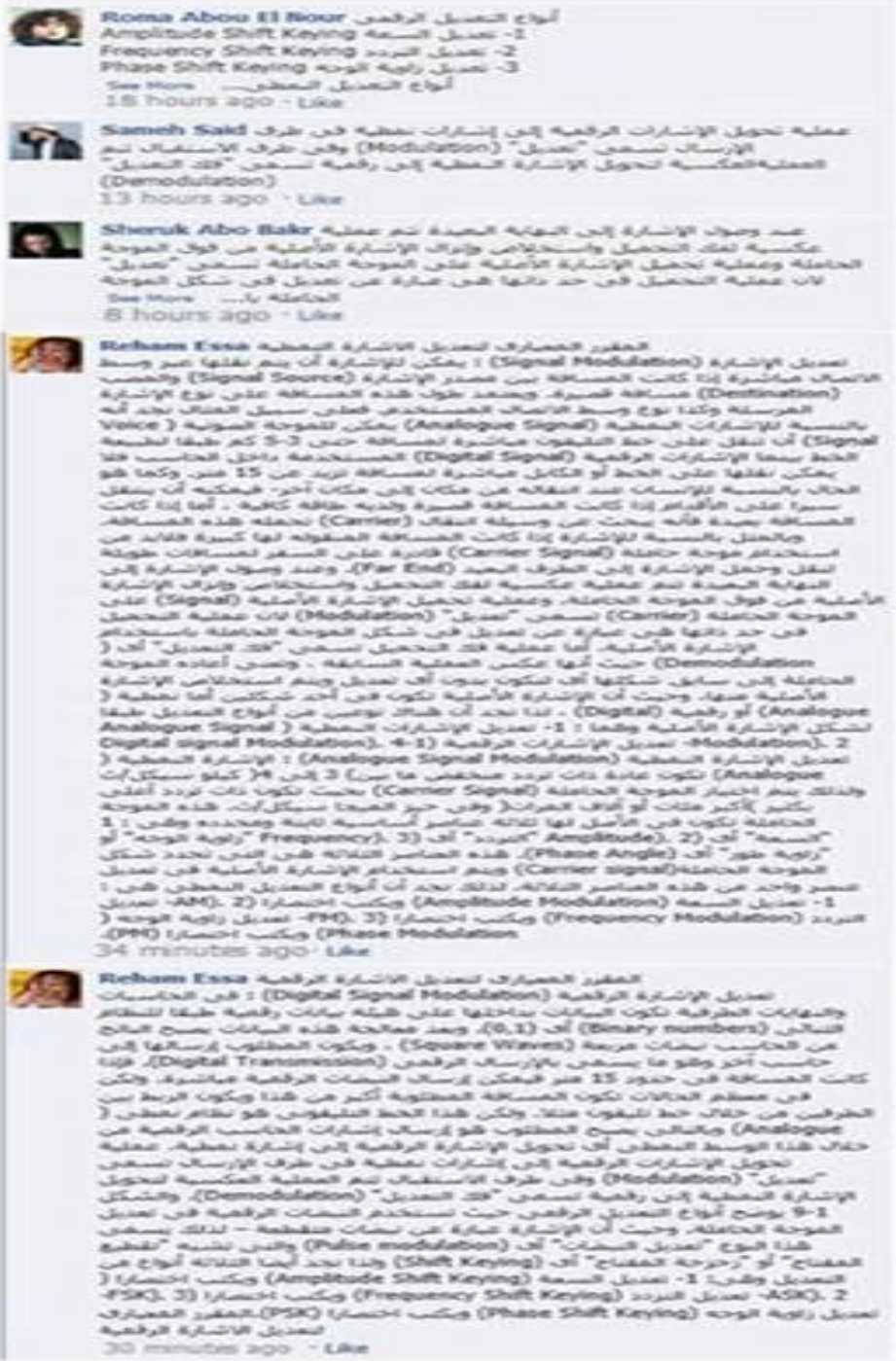




\begin{tabular}{|c|c|}
\hline Element & target \\
\hline $\begin{array}{l}\text { 1. simplified model system for contact (Simple } \\
\text { Communication System) }\end{array}$ & $\begin{array}{l}\text { 1. Remember specific } \\
\text { definition of the concept of } \\
\text { network Network. }\end{array}$ \\
\hline $\begin{array}{l}\text { "Sender" (Transmitter) . } \\
\text { "Future" (Receiver) . } \\
\text { "Channel of communication" (Communication Channel) . }\end{array}$ & $\begin{array}{l}\text { 2. Contact know the } \\
\text { system components. }\end{array}$ \\
\hline Sender and receiver protocols & $\begin{array}{l}\text { 3. Know the meaning } \\
\text { Protocol clear definition. }\end{array}$ \\
\hline \begin{tabular}{|l|} 
"Encoded" (The Coder) \\
"the average" (Modulator)
\end{tabular} & $\begin{array}{l}\text { 4. Know the sender } \\
\text { components. }\end{array}$ \\
\hline $\begin{array}{l}\text { Telephone call model } \\
\text { Use the computer to connect to the Internet: }\end{array}$ & $\begin{array}{l}\text { 5. Know the precise } \\
\text { definition of the } \\
\text { communication channel. }\end{array}$ \\
\hline $\begin{array}{l}\text { "Reagent Amendment" (Demodulator) } \\
\text { "Decoding code" (The Decoder) }\end{array}$ & $\begin{array}{l}\text { 6. Know the future } \\
\text { components. }\end{array}$ \\
\hline $\begin{array}{l}\text { Transmission patterns (Transmission Modes) } \\
\text { - Send in one direction and the so-called } \\
\text { "simplex"(Simplex). } \\
\text { - Send in two directions at the same time and so-called } \\
\text { "full duplex" (Full Duplex) } \\
\text { - Send in two directions, but not at the same time, this } \\
\text { type is an intermediate state between these two } \\
\text { extremes is called a "half duplex" (Half Duplex) }\end{array}$ & $\begin{array}{l}\text { 7. The multiplicity of } \\
\text { different transmission } \\
\text { patterns. }\end{array}$ \\
\hline $\begin{array}{l}\text { 1. Send in one direction and the so-called } \\
\text { "simplex"(Simplex) Any "single" or "simple" } \\
\text { Send in two directions at the same time and so-called } \\
\text { "full duplex" (Full Duplex) Ie, "full duplex" } \\
\text { Send in two directions, but not at the same time, this } \\
\text { type is an intermediate state between these two } \\
\text { extremes is called a "half duplex" (Half Duplex) Any } \\
\text { "half-duplex" }\end{array}$ & $\begin{array}{l}\text { 8. Simplex distinguish } \\
\text { between full duplex and } \\
\text { half duplex. }\end{array}$ \\
\hline $\begin{array}{l}\text { "Modem" } \\
\text { Unit amendment (Modulator) } \\
\text { Unit detector amendment (Demodulator) }\end{array}$ & $\begin{array}{l}\text { 9. The multiplicity of parts } \\
\text { made up of the unity ofthe } \\
\text { modem. }\end{array}$ \\
\hline $\begin{array}{l}\text { "Codec" (Codec) } \\
\text { Unit encoded (Coder) } \\
\text { Decoder code (Decoder) } \\
\end{array}$ & $\begin{array}{l}\text { 10. Multi-codec unit } \\
\text { constituent parts. }\end{array}$ \\
\hline $\begin{array}{l}\text { 3. transmission constraints (Transmission } \\
\text { Impairments) : } \\
\text { Distortion decay (Attenuation Distortion) } \\
\text { Distortion Delay (Delay Distortion) } \\
\text { LNB (Noise) }\end{array}$ & $\begin{array}{l}\text { 11. The multiplicity of the } \\
\text { obstacles affecting } \\
\text { thesignal. }\end{array}$ \\
\hline $\begin{array}{l}\text { Thermal LNB (Thermal Noise) } \\
\text { LNB impulses (Impulse Noise). }\end{array}$ & $\begin{array}{l}\text { 12. The discriminate } \\
\text { between different types of } \\
\text { LNB. }\end{array}$ \\
\hline $\begin{array}{l}\text { 4. Edit Bookmark (Signal Modulation) : } \\
\text { 1. Amendment typical signals (Analogue Signal } \\
\text { Modulation) . } \\
\text { 2. Amendment digital signals (Digital signal } \\
\text { Modulation). }\end{array}$ & $\begin{array}{l}\text { 13. LNB know the impact } \\
\text { on the received signal and } \\
\text { modify the signal. }\end{array}$ \\
\hline $\begin{array}{l}\text { Amplitude modulation (Amplitude Shift Keying) } \\
\text { Frequency modulation (Frequency Shift Keying) } \\
\text { Modified flip angle (Phase Shift Keying) }\end{array}$ & $\begin{array}{l}\text { 14. Know the relationship } \\
\text { that describes the ratio } \\
\text { between the reference and } \\
\text { LNB and the types of } \\
\text { modulation. }\end{array}$ \\
\hline
\end{tabular}


- The development of learning strategy based on social networks (Facebook) For the basics of data communication systems.

- Page design entitled: the basics of communications systems.Https://www.facebook.com/groups/679880095 451494 /

And clicking on the central transmitter comments appear as in Figure follows:

Set the standard in the signal typical digital signal:

- The research sample selection and divided into two groups (the control group) experimental group.

- The application of cognitive achievement test on the sample search application tribal.

- Card application of Note to tribal communication skills.

- The study by groub Educational interactive on Facebook for communication media.

- The application of cognitive achievement test on the sample application after me.

- Application note for communication skills Uday card.

- Conducting statistical treatment of the data.

- Reach and interpretation of the results and discussed.

\section{Test the validity of hypotheses:}

To test the validity of the first hypothesis which Ats Ali "There were statistically function teams at the level $(\leq 0.05)$ between the mean scores of the two groups students (Altjeribh and control group) in the collection of knowledge to the unity and means of communication decision Computer Networks robot with the Division of Science students of Computer Higher Institute of Management and Information Technology, Kafr ElSheikh for the experimental group.

Alp has urged him using a t-test through statistical package SPSS for Windows V (17) For comparison between the two groups (experimental $\mathrm{n}_{1}=30$, control $\mathrm{n}_{2}=30$ ) in the application and Alquili dimensional difference between the two 
averages of the two groups to test students in grades, and Table 1 below illustrates this:

Table (1):Pain averages and standard deviations and the values of

(T) and the level of significance For comparison between the two groups (experimental and control) in the test grades

\begin{tabular}{|c|c|c|c|c|c|}
\hline Application & Groups & M & $\mathbf{P}$ & Value $(\mathrm{T})$ & $\begin{array}{l}\text { The level of } \\
\text { significance }\end{array}$ \\
\hline \multirow{2}{*}{ tribal } & Trial & 11.100 & 3.477 & \multirow{2}{*}{0.116} & \multirow{2}{*}{0.908} \\
\hline & Officer & 10.966 & 5.343 & & \\
\hline \multirow{2}{*}{ After me } & Trial & 33.733 & 1.089 & \multirow{2}{*}{7.740} & \multirow{2}{*}{0.001} \\
\hline & Officer & 24.167 & 5.675 & & \\
\hline \multirow{2}{*}{$\begin{array}{c}\text { The } \\
\text { difference } \\
\text { between the } \\
\text { two }\end{array}$} & Trial & 22.633 & 1.295 & \multirow[b]{2}{*}{10.652} & \multirow[b]{2}{*}{0.001} \\
\hline & Officer & 13.200 & 3.575 & & \\
\hline
\end{tabular}

Seen from the above table; Table (1) that there is a D between the two teams in the achievement in all of the dimensional application and the difference between the two applications pre and post, which indicates the presence of significant difference between Almjmuat yen (experimental and control) at the level of significance $(\leq 0.05)$ in the collection dimensional application in $\mathrm{x}$ automatically from the impact of the application for the benefit of the tribal group Walt follicular Her average for being the top. Tadhu researcher and that of the effectiveness of Facebook.

To test the validity of the second hypothesis which yen $\mathrm{p}$ Ali "There is the same function teams statistically at $(\leq 0.05)$ between the mean scores of the two groups students (Altjeribh and control group) in the performance skills unit and media decision Computer Networks robot with the Division of Science students of Computer Higher Institute of Management and Information Technology in Kafr Sheikh.

Alp has urged him using a t-test through statistical package SPSS for Windows V (17) For comparison between the two groups (experimental $\mathrm{n}_{1}=30$, control $\mathrm{n}_{2}=30$ ) in the application and Alquili dimensional difference between the two averages in the students Almjmootai ducks $\mathrm{Ge}$ navigator portfolio, and Table 2 below illustrates this: 
Table (2) Averages and standard deviations and the values of (T) and the level of significance For comparison between the two groups (experimental and control) in Note Card

\begin{tabular}{|c|c|c|c|c|c|}
\hline Application & Groups & M & $\mathbf{P}$ & Value (T) & $\begin{array}{l}\text { The level of } \\
\text { significance }\end{array}$ \\
\hline \multirow{2}{*}{ tribal } & Trial & 5,200 & 7.152 & \multirow{2}{*}{0.578} & \multirow{2}{*}{0.566} \\
\hline & Officer & 4.206 & 7.148 & & \\
\hline \multirow{2}{*}{ After me } & Trial & 67,000 & 6.822 & \multirow{2}{*}{13.109} & \multirow{2}{*}{0.001} \\
\hline & Officer & 25.166 & 15.523 & & \\
\hline \multirow{2}{*}{$\begin{array}{c}\text { The } \\
\text { difference } \\
\text { between the } \\
\text { two }\end{array}$} & Trial & 61.800 & 8.313 & \multirow[b]{2}{*}{16.262} & \multirow[b]{2}{*}{0.001} \\
\hline & Officer & 20.810 & 11.309 & & \\
\hline
\end{tabular}

It is seen from the above table; Table (2) that there is a D between the two teams in skill performance in each of the dimensional application and the difference between the two applications pre and post indicating the presence of significant difference between Almjmuat yen (experimental and control) at the level of significance $(\leq 0.05)$ in performance skills in the post application automatically $\mathrm{x}$ the impact of the application for the benefit of the tribal group Walt follicular Her average for being the top. Tadhu researcher and that of the effectiveness of Facebook.

\section{References}

\section{First: The Arabic references:}

Ibrahim Abdul Wakil mouse (2012). Educations twenty-first century technology: technologies (Web 2.0), the Arab Thought House, Cairo.
AHamad
Khater
et
al. . (1987). Studies
in

motor learning, Cairo: Dar Knowledge 0.1987.

Ghada Abdullah girl vertical (2005). Social Software in the learning system based on the Web: social networking model, the Arab Open University - Saudi Arabia - Jeddah.

Mordant bin Faris Al-Otaibi (2011). "The use of students of Saudi universities Advanced Network .. An Empirical Study", Master Thesis, Faculty of Arts, King Saud University. Jewels Girl apparent Mohammed Anzi 
(2013): effectiveness Use Networks Communication Social In Collectin g Science And the trend about Community Knowledge to Students Class the third Average City Medina, Umm Al Qura University, Medina.

Dilshad Mohammad Sharif (2012). Effectiveness of the training program for the development of social communication skills among a sample of children with autismPhD

Thesis, Faculty of Education, University of Damascus.

Slaves, Thuqan_Suhaila Abu semolina, (2005). Teaching strategies_Atheist-first century_Teacher and supervisor guide_Educational, i 1.1426 e_2005_M., De Bono House Publishing_And distribution, Amman, Jordan,_P. 129 130.

Lamis Shalash (2013). The employment of Facebook in e-

Learning - Open Learning Centre of the University of cod Q Open.

Maher Arafat (2011). Impact of Social Teaching of the use of social networks and Facebook on the Faculty of Information Technology students at An-Najah NationalUniversity, Palestine 0.2011.

Mohamed Shawky Shaltout (2013) - Facebook as a learning management.

Encyclopedia of education and training, in November 2009 www.edutrapedia.illaf.net

Himmat gift of Mr. Kassem (2013). Effectiveness of the proposed system of participatory learning environment via the Internet in the development of problem-solving skills and attitudes towards learning environment to the students of Educational Technology, Faculty of Specific Education, Ain Shams University.

India girl Caliph Suleiman (2010). A comparison of blogs and bridges system for the management of e-learning, King Saud University, Riyadh.

Wajih Mahjoub (2002). Physiological learning, Amman: Dar Thought for printing, publishing and distribution. 


\section{Second: English References}

Dalsgaard, C. (2006). Social Software: E-Learning Beyond Learning Management Systems. Of the free Open Journal European, Distance And E-Learning. Online Available Http://www.eurodl.org/materials/contrib/2006 LChristian Dalsgaard.htm

Daved, Dan (2008). How Facebook And Myspace Affect Communication In The Physical World, Research Paper.

Jennifer Hofman. (2003). Creating Collaboration Http://www. learningcircuits.org/2003

Hotrum, M. (2005). Breaking Down The Walls LMS. The International Review of Research In the free Open And Distance Learning, Vol 6, No 1 (2005), ISSN: 14923831.http://librariansmatter.com/blog/2007/10/18/socia l-networking-tools-and-university-teaching/

O'Reilly, Tim. What Is Web 2.0: Design Patterns And Business Models For The Next Generation Of Software .O'Reilly, 2005 .- Accessed June 12, 2008 .- Available At :Http://www.oreillynet.com/pub/a/oreilly/tim/news/ 2005/09/30/what-is-web-20.html

Pantiz, Ted. (1996) Collaborative Versus Cooperative Learning- A Comparison of The Two Concepts Which Will Helps Us Understand Nature Of The Underlying Interactive Learning . Available: Http://home.capecod. net/ tpanitz/tedsarticles Preece, Jennifer. (2002). Interaction Design: Beyond HumanComputer Interaction. Gohan Wiley

Trentin, Guglielmo. (1999). Network Based Collaborative Education. Instructional Journal of Instructional Media, v (26), n (2)

A. Pempek Tiffany, et al (2009): College Students' Social Networking On Facebook Experiences, Journal of Applied Developmental Psychology 30,227-238.

Wiersema, Nico. (2000). How Does Collaborative Learning Actually workTel In A Classroom And How Do Students React To A Brief Reflection It? Available. Www.city. London met.ac.uk 
Wilhelmsen, Sonja And Asmul, Stein Inge And Meistad, Gyvind (2002): A Collaborative Tern Papper In the Project Pedagogical Information Science, Department Of Information Science, University Of Bergen, Norway, Nov. 27, p P.28: 31

Cottrell, S. (1999): The Study Skills Handbook. London:

Macmillan press Ltd.

\section{Third: Web sites:}

http://www.edutopia.org/how-use-social-networking-

technology

http://rs.ksu.edu.sa/68758.html

http://Education.own0.com

http://www.youtube.com/watch?v=vrmGz]KU2JQ\&feature=relat ed

http://www.aitnews.com/latest-it-news/technology-researchand-studies-news / 104511.html

http://www.ye1.org/vb/showthread.php?t=5632211 
